\title{
Pandemic, social distancing and academia - Dancing in the dark 20 years later
}

\author{
PhD. Hélio ARThur ReIS IRIgaraY ${ }^{1}$ \\ ${ }^{1}$ Fundação Getulio Vargas / Brazilian SChool of Public and Business Administration, Rio de Janeiro - RJ, BraziL
}

On March 11 of this year, the World Health Organization (WHO) declared that the world was facing a new pandemic (WHO, 2020), this time caused by SARS-CoV-2 (severe acute respiratory syndrome coronavirus 2 ), which is the etiological agent of COVID-19, a respiratory infectious disease, for which there is neither a vaccine nor a proven effective treatment (SINGHAL, 2020).

The indicated prevention measures are thorough handwashing with soap and water, the use of hand sanitizers, the use of a face mask, and social distancing. This distancing aims to reduce interaction and proximity between people in a community, where individuals are infected, but not yet identified, and can transmit the disease (HE, DENG and LI, 2020).

However, according to the National Continuous Household Sample Survey (PNAD), of 2018, 31.1 million Brazilians live in households without access to a main system water supply; 74.2 million, in areas without a sewage system; 5.8 million do not have a bathroom in their home; and 11.6 million live in densely populated properties, that is, with more than three residents per bedroom (IBGE, 2020). How can social distancing occur in these conditions? The suggested policy applies to an economically privileged minority.

The same can be said of economic activities: $23 \%$ of Brazilians have entirely lost their source of income, and $17 \%$ have had a reduction in their monthly earnings (CNI, 2020).

But even for those who do not fall into these categories - for example, many of us, professors and academics - how have professional activities changed?

First of all, we have to recognize our privilege: our profession is socially valued, we have guaranteed labor rights that allow us to reflect on the challenges that synchronized lessons mediated by technology impose on us, as well as on the type of teaching and work relationships we want.

From one hour to the next, we saw our classes and academic meetings completely migrate to the digital environment, which forced us to learn new systems, rethink pedagogical methods, rewrite our lesson plans, insert new content, with unprecedented speed and sense of urgency.

Our daily tasks grew exponentially and, more than that, started to demand skills in which we were not always proficient. We were forced to manage our anxieties and, also, those of our students, peers, superiors, administrative colleagues. In the background of all this, there is intense organizational pressure for performance and results, and the specter of uncertainty about the future. In many educational institutions, professors are evaluated the end of each course. The insecurity with technological tools both by professors and students, and the management of class time can become factors that compromise the perceived quality of the course. In addition, in some cases, professors are faced with the threat of reduced wages, higher workload, and even with the termination of employment. This new configuration of the world of work has resulted in an emotional burden.

Professors are, as never before, faced with the need to rethink and manage their career, under the shadow of an "economic crisis unprecedented in history" (FMI, 2020) and having to negotiate for their jobs, accepting to carry out additional unpaid activities (training, meetings).

As with other professional categories that also moved to work from home, social distancing forced professors and academics to deal with the fragile frontier that separated their personal and professional lives. Professionals are challenged to balance 
multiple identities within their home space, with a heavy load of physical and emotional work on their shoulders. Now, the home is the place of work, no longer a place of refuge and rest. The residence, once privately owned, has been incorporated as part of an enterprise.

Social distancing exacerbated the patriarchal and sexist side of Brazilian society; since the confinement of people to their homes aggravated domestic violence against women (MODELLI, 2020) and the LGBTQIA+ population (LISBOA, 2020). The home, once described as the antipode of work, has proved to be the space in which women face the greatest burden of unpaid work. This reality is not only characteristic of the less favored socio-cultural classes. There is evidence that the work of the academics, which has been the object of previous studies - such as Miranda, Cappelle, Fonseca et al. (2013) -, was even more compromised in this first quarter of 2020 since the submission of academic articles by women fell by $12 \%$ (CÂNDIDO and CAMPOS, 2020).

Another important impact of social distancing is the "desertification" of the physical space of universities and colleges. Seeing our offices, classrooms, libraries, and empty corridors is a distressing experience. As much as social media, applications, and digital solutions enable contact, we miss the lessons, meetings, and advising sessions... Where is everybody? Where are we? Social distancing creates the feeling of endless suffering, of being in darkness, where the only hope lies in a romanticized past. This whole scenario brings us closer to Selma Jezková, the protagonist of the film Dancer in the Dark, written and directed by Lars Von Trier, released twenty years ago.

The distressing plot unfolds in the 1960s, in the United States, and portrays the life of Selma Jezková, single mother of Gene, a 12-year-old boy. Selma has a hereditary degenerative disease that causes a consuming and progressive blindness, a disease that her child will eventually develop.

She emigrates to the US to get surgery for her son. They live in a rented trailer, and she works as a metallurgist in a factory, engages in musical rehearsals in the theater and dreams of Hollywood musicals.

Despite adopting a similar argument, the film differs from Latin American soap operas and American musical comedies, because not everything ends well. The protagonist is not a princess to be saved by a prince charming. Aware of the precarious health condition and her increasingly impaired eyesight, Selma fights for her dignity on a daily basis, without letting down her guard or incorporating the melodramatic role of "helpless maiden." On the contrary, at no time does she take advantage of these limiting conditions to make people feel sorry for her. She continues to fight day after day to overcome these barriers and provide her son with a different future.

Due to her illness, Selma is involved in an accident at work and ends up breaking a machine, which results in her dismissal. At this moment, her friend Jeff realizes that she can hardly see. Selma, without the slightest self-pity, affirms that "in musicals, there are no problems," and then sings to him, "I already saw everything I needed to see in life."

Her life takes a tragic turn when she is deceived by her friend Bill, a police officer who steals her money to avoid bankruptcy. Bill had promised never to tell anyone about Selma's health condition; she, in turn, promised never to reveal that he has gone into debt to satisfy all his wife's consumerist desires.

In a deliberate and planned act, taking advantage of Selma's visual limitation, Bill steals all the money she has saved. Selma tries to get the money back, explains to her friend that she needs to pay the doctor, because in a few days she will be completely blind, but he is determined not to return the money. Faced with Selma's insistence, Bill starts to shout, claiming he is the one being robbed; he takes a gun and, while they are pushing each other, Bill ends up being shot, but does not die. Injured, he begs Selma to kill him, so that his wife will never discover the truth about his real financial situation. Completely upset, the immigrant does what her friend asks. Bill dies. Selma is arrested, tried, and sentenced to death, without ever revealing Bill's secret and the true origin of the money, which could have saved her life. Despite everything, she was true to herself and her friend until the end.

Trier uses Selma as a metaphor to criticize the American system, to unmask the American Dream and its presumed meritocracy, as well as to denounce a society and a system where the weak and honest have no time. 
If in the first part of the film, the dreams of the Czech immigrant were hijacked by the company where she worked, in the second part of the film, she becomes a victim of the American legal system: without money to pay for a lawyer, she is defended by a professional appointed by the Court. In this sequence, Trier takes out the voice of the main character, while the prosecutor, with good rhetoric, convinces the jury to convict her.

As for us, we use Selma as a metaphor for professors and academics in this moment of social distancing and working from home. Similar to the protagonist in the first part of the film, we behave like workers of knowledge and teaching, whose articles and lessons are produced on an assembly line. We believe, or pretend to believe (GOFFMAN, 1959), in meritocracy (one day all our efforts will be recognized) and in the productivity logic; we naturalize the expectations for excellence, for the intensification of our academic production (since we are at home), and adaptation to the new forms of offering lessons. Thus, we become the postmodern subjects of performance described by Han (2019). We are trapped and vigilant within ourselves at all times, doomed to carry our own prison.

Like Selma, we are 'losing sight.' We are actually losing sight of ourselves, while we introject the negativity of the superego, which restricts the freedom of the ego, and replace it with the projection of the "ideal self." At the limit, we are competing with ourselves, and, as the ideal self proves to be unattainable, we consider ourselves as a failure.

However, like Selma, we remain faithful and honest to our purpose of offering quality lessons and academic production. We want to contribute so that our students are able to reflect and think critically. We hope that our scientific work opens new paths in our field of knowledge and indicate a possible - and better - future for our society and organizations. However, science often faces an anti-Enlightenment crusade. We are offended and condemned by society and its official representatives, who perceive science and knowledge as national enemies. Notwithstanding, none of these condemnations come close to the intensity of our self-judgment flooded with guilt, the feeling that we are not producing as much as we could, we want, with the desired originality and relevance, nor offering lessons with the quality that we want.

Once again, like Selma, we are 'Dancers in the Dark,' caught up in the days to come, questioning our ability to propose new ideas, theories and reflections, and even the purpose of our social role and our ability to engage in academia and society as a whole.

As professors and academics, we have to recover the raison d'être of universities, colleges, and teaching and research institutions. These organizations cannot be limited to the role of companies with business models, whose sole objective is to maximize profits. We are research centers; we generate knowledge, we contribute to the economic and social development of Brazil. Our social role is to (re)think about our country, get involved, and propose solutions to national problems.

We cannot be seduced by the discourse - and practice - of transforming lessons in extravagant shows, mediated by technology. It is our obligation to reflect not only on teaching methods but, fundamentally, on the contents of our courses. The courses must enable students to reflect and act.

We can never forget that our institutions are communities embracing different stakeholders - academics, students, administrative staff, our peers, other institutions, associations, professional associations and government agencies, as well as society per se -, and we must develop new collaborative ways of working.

This is the challenge that lies ahead.

I invite our readers to begin this reflection by enjoying the articles published in this issue of Cadernos EBAPE.BR.

We begin with the work by Rubens Mussolin Massa, Raul Beal Partyka, and Jeferson Lana, entitled 'Behavioral agency research and theory: a review and research agenda' which presents the argument that executive's performance compensation, according to agency theory, is the most used mechanism to stimulate executives to make decisions toward the company's growth and best performance.

The next study is 'Unveiling the concept of transparency: its limits, varieties, and the creation of a typology,' by Karina Furtado Rodrigues. The author proposes a typology that has four subtypes of transparency in organizations: (1) full transparency; (2) nominal transparency; (3) conditioned transparency; (4) transparency in the classification and management of sensitive information. 
The work by Lucas Casagrande and Nilo Coradini de Freitas, 'Organizing in the age of systems: Ivan Illich's critical contributions to organization studies,' presents Ivan Illich's thinking and contributions to organizational studies.

Gean Carlos Tomazzoni and Vânia Medianeira Flores Costa's article 'Antecedents and consequences of organizational commitment, entrenchment, and consent,' presents a model that analyzes the influence of organizational values as antecedent variables of the individual's commitment, entrenchment, and consent with the organization.

The article by André Rehbein Sathler and Roberto Campos da Rocha Miranda 'Who are the Brazilian companies and what do they do? Analyses of mission statements delineate the largest Brazilian companies' identity profiles based on their mission statements.

Bárbara Katherine Faris Biondini, Rossi Henrique Soares Chaves, and Janaynna de Moura Ferraz produced an essay analyzing the film "I, Daniel Blake" in their work 'Lukács and the aesthetic particularity of wage labor and the mediation of the state bureaucracy in 'I, Daniel Blake.'

In turn, the contradictions of a model of corporate social responsibility are the subject of Juliana Campos Lopes and Jacques Demajorovic's research, entitled 'Corporate social responsibility: a critical view from the case study of Samarco's socioenvironmental tragedy.'

In 'Government planning in Brazilian municipalities: toward a research agenda,' Luciana Leite Lima, Lizandro Lui, Gianna Vargas Reis Salgado Dias, Luciana Pazini Papi, and Diogo Joel Demarco investigate the scientific production on municipal planning.

Mara Vogt, Edmery Tavares Barbosa, Marcia Zanievicz da Silva, and Arno Paulo Schmitz describe the determinants of salary differences among accounting professionals in Brazil, in 'The wage gap in accounting positions.'

'What is it like to be an indigenous student of business administration?' is the research question explored by Renan Carlos Klichowski, Marcio Pascoal Cassandre, and Wagner Roberto do Amaral. The authors seek to identify and analyze the understandings, expectations, and dilemmas present in the education of indigenous students attending business administration programs in universities of the Brazilian state of Paraná.

The analysis of the relationship between time and consumer culture in modernity, and its influence on human experiences, from a critical perspective of administration, is the theme of the study 'Acceleration, social time, and consumer culture: notes on (im)possibilities in the field of human experiences,' written by Carlos Victor Leal Aderaldo, Cassio Adriano Braz de Aquino, and Maria de Fátima Vieira Severiano.

In 'Market-based places, diversity, and intersectional exclusion,' Paulo Roberto Chaves Dalpian and Teniza da Silveira discuss how the incidence of intersectionality operates within market-based places that present themselves as diverse or open to diversity - specifically gay market-based places.

The analysis of the construction of the identities of evangelical prostitutes working in a red-light district of a large Brazilian city is the object of the article 'Between the sacred and the profane: identities, paradoxes, and ambivalences of evangelical prostitutes from a red-light district of Belo Horizonte,' by Jefferson Rodrigues Pereira, José Vitor Palhares dos Santos, Alice Gerlane Cardoso da Silva, Kely Cesar Martins de Paiva, and Alexandre de Pádua Carrieri.

This issue presents the guest article, 'Female leadership: perceptions, reflections, and challenges in public administration,' written by Renata Kessler Miltersteiner, Fátima Bayma de Oliveira, Lygia Gonçalves Costa Hryniewicz, Anderson de Souza Sant'Anna, and Luiz Carlos Moura. The authors seek to better understand the challenges faced by women in public administration positions in the government of the Brazilian state of Rio de Janeiro.

Concluding this issue, we offer our readers the bibliographical review 'Guerreiro Ramos' forbidden book,' which deals with 'Myth and truth of the Brazilian revolution.' In this work, Guerreiro Ramos criticizes the roots of Stalinism, pointing out the challenges of the transformation of contemporary Brazil.

We wish you a pleasant read!

PhD. HÉlio ARTHUR REIS IRIgARAY

EDITOR-IN-CHIEF 


\section{REFERENCES}

CÂNDIDO, M. R.; CAMPOS, L. A. Blog Dados, 14 maio 2020. Available at: <http://dados.iesp.uerj.br/pandemia-reduz-submissoes-demulheres/>. Accessed on: May 20, 2020.

CONFEDERAÇÃO NACIONAL DA INDÚSTRIA - CNI. Três em cada quatro brasileiros vão manter redução de consumo após a pandemia. Agência CNI de Notícias, Brasília, 07 maio 2020. Available at: <https:// noticias.portaldaindustria.com.br/noticias/economia/tres-em-cadaquatro-consumidores-vao-manter-reducao-no-consumo-no-pospandemia/>. Accessed on: May 07, 2020.

FUNDO MONETÁRIO INTERNACIONAL - FMI. World Economic Outlook Reports: The Great Lockdown. 2020. Available at: <https://www. imf.org/en/Publicatio ns/WEO/Issues/2020/04/14/weo-april-2020>. Accessed on: May 20, 2020.

HAN, B. C. A Sociedade do Cansaço. Rio de Janeiro: Editora Vozes, 2019.

HE, F.; DENG, Y.; LI, W. Coronavirus Disease 2019: What We Know? J Med. Virol., Early view, p. 1-7, 2020. Available at: <https://doi. org/10.1002/jmv.25766>. Accessed on: May 20, 2020.

INSTITUTO BRASILEIRO DE GEOGRAFIA E ESTATÍ́STICA - IBGE. Pesquisa Nacional por Amostra de Domicílio Contínua - PNAD Contínua. 2020. Available at: <https://www.ibge.gov.br/estatisticas/sociais/ populacao/9171-pesquisa-nacional-por-amostra-de-domicilioscontinua-mensal.html>. Accessed on: May 15, 2020.
LGBTIS vivem acirramento de violência familiar em isolamento social. Folha vitória, Espírito Santo, 17 maio 2020. Available at: <https:// www.folhavitoria.com.br/ geral/noticia/05/2020/Igbtis-vivemacirramento-de-violencia-familiar-em-isolamento-so cial>. Accessed on: May 20, 2020.

LISBOA, V. LGBTIs vivem acirramento de violência familiar em isolamento social. Agência Brasil, Rio de Janeiro, 17 maio 2020. Available at: <https://agenciabrasil.ebc.com.br/direitos-humanos/ noticia/2020-05/Igbtis-vivem-acirramento-de-violencia-familiar-emisolamento-social>. Accessed on: May 17, 2020.

MIRANDA, A. R. A. et al. O exercício da docência universitária por docentes mulheres. Pretexto, Belo Horizonte, v. 14, n. 1, p. 106-123, 2013.

MODELLI, L. Violência física e sexual contra mulheres aumenta durante isolamento social provocado pelo coronavírus. G1, Rio de Janeiro, Seção Bem Estar, 19 abr. 2020. Available at: <https://g1.globo.com/ bemestar/coronavirus/noticia/2020/04/19/violencia-fisica-e-sexualcontra-mulheres-aumenta-durante-isolamento-social-provocadopelo-coronavirus.ghtml>. Accessed on: May 16, 2020.

SINGHAL T. A. Review of Coronavirus Disease-2019 (COVID-19). The Indian Journal of Pediatrics, v. 87, n. 4, p. 281-286, 2020.

WORLD HEALTH ORGANIZATION - WHO. Novel Coronavirus 2020. 2020. Available at: <https://www.who.int/emergencies/diseases/ novel-coronavirus-2020>. Accessed on: May 15, 2020.

PhD. Hélio Arthur Reis Irigaray

ORCID: https://orcid.org/0000-0001-9580-7859

PhD from FGV EAESP; Master's in business administration from PUC-Rio; Bachelor degree in economics from the University of Northern lowa, USA; Adjunct professor at FGV EBAPE and the Corporate International Master Program (CIM), Georgetown University, Washington, USA; Leader of the theme 'diversity and labor relations' in the line of research 'work management' (ANPAD). E-mail: helio.irigaray@fgv.br 